\title{
Allergic diseases of the skin and drug allergies - 2018. Risk factors for hypoproteinemia in infantile atopic dermatitis
}

Geunhwa Park

From 2nd WAO International Scientific Conference (WISC 2012)

Hyderabad, India. 6-9 December 2012

\section{Background}

Hypoproteinemia is one of complications of severe atopic dermatitis. The aim of this study was to investigate the risk factors for hypoproteinemia in atopic dermatitis.

\section{Methods}

Seventy seven infants with atopic dermatitis were enrolled, who visited pediatric allergy clinic of Busan St. Mary's Medical Center from January 2005 to January 2012. Infants with serum protein level was lower than normal range for age were classified to Group A $(n=27)$ and normalto Group B $(n=50)$. Age, sex, family history of allergy, and SCORAD score were studied. We examined platelet count, CRP, eosinophil count, serum albumin and protein, also serum ECP, total IgE, and allergen specific IgE by immuno CAP system (Phadia AB, Uppsala, Sweden). We identified skin wound culture and mycoplasma infection.

\section{Results}

Group A (Atopic dermatitis with hypoproteinemia) had higher SCORAD score, eosinophil count, CRP, ECP, and total IgE, and lower albumin than control group. Serum protein had statistically significant correlations with SCORAD score, eosinophil count, albumin, total IgE and number of sensitized allergens, but had not with CRP and ECP.

\section{Conclusions}

The lower serum protein, the more severe atopic dermatitis. Our study suggests that the risk factors for hypoproteinemia in infantile atopic dermatitis were high

Busan St. Mary's Medical Center, South Korea
SCORAD score, eosinophil count, total IgE, and number of sensitized allergens, and low albumin.

Published: 23 April 2013

doi:10.1186/1939-4551-6-S1-P105

Cite this article as: Park: Allergic diseases of the skin and drug allergies 2018. Risk factors for hypoproteinemia in infantile atopic dermatitis. World Allergy Organization Journal 2013 6(Suppl 1):P105.
Submit your next manuscript to BioMed Central and take full advantage of:

- Convenient online submission

- Thorough peer review

- No space constraints or color figure charges

- Immediate publication on acceptance

- Inclusion in PubMed, CAS, Scopus and Google Scholar

- Research which is freely available for redistribution
C Biomed Central (c) 2013 Park; licensee BioMed Central Ltd. This is an Open Access article distributed under the terms of the Creative Commons Attribution License (http://creativecommons.org/licenses/by/2.0), which permits unrestricted use, distribution, and reproduction in any medium, provided the original work is properly cited. 